\title{
BARRIERS TO THE ADOPTION OF THE INTERNET AND SELECTION OF E-COMMERCE ACTIONS: INCIDENTAL MOTIVATIONS OF MICRO-ENTREPRENEURS
}

\author{
Gustavo BARRERA VERDUGO
}

\author{
Facultad de Ingeniería y Negocios, Universidad de Las Américas, Sede Providencia, \\ Manuel Montt 948, Santiago, Chile \\ E-mail: gbarrera@udla.cl
}

Received 26 December 2018; accepted 24 June 2019

\begin{abstract}
For decades entrepreneurial motivations have been related to entrepreneurial behavior, in areas such as investments or formulation of strategies, however, its link with the adoption of e-commerce in microenterprises has not been explored in depth. Likewise, most of the research on e-commerce has been focused on studying small and medium-sized companies. Consequently, this research aims to assess the relationship of motivations of micro-entrepreneurs when developing their businesses, with the barriers they perceive to adopt the Internet, and the types of e-commerce activities they implement in their companies. In addition, demographic variables are analysed in order to facilitate the categorization of these organizations. Logistic regressions and Chisquare statistics are developed, on data published in the Fifth Micro-Entrepreneurship Survey of Chile. The results obtained show that the motivation for entrepreneurship based on family tradition is related to less Internet adoption and uses for e-commerce; also, it is evidenced that necessity and opportunity-based motivations are positively associated with Internet use for relationship purposes with clients and suppliers. This information is considered relevant in practical terms, since it allows strengthening the use of e-commerce in microenterprises, through the implementation of programs to support microentrepreneurs with incident characteristics, under the financing of governmental entities or private companies.
\end{abstract}

Keywords: internet barriers, e-commerce uses, micro-enterprises, entrepreneurial motivations, demographic conditions.

JEL Classification: L81, L86, L26, D91.

\section{Introduction}

Adoption and use of Information and Communication Technologies (ICT) is a relevant condition for companies to be competitive (Gutiérrez-Leefmans and NavaRogel 2016). Nowadays, enterprises use Internet-based technologies that allow them to compare or exceed the performance of competitors in sales promotion, sales, and relationship with customers (Bianchi and Mathews 2016). In the context of micro-enterprises, the use of the Internet in marketing and production functions is an opportunity (Fillis et al. 2003, Nikunen et al. 2017, Lin et al. 2018), since it facilitates access to a large number of potential clients and relationship option with service providers. Under these new conditions, an enterprise consisting of less than 10 employees, could sell its products to thousands of customers and interact with them through applications linked to the web.

Given the importance of the Internet and e-commerce for sales and business development, many researchers have been focused on studying the conditions that favour its adoption as well as the barriers that hinder it. Ihlström et al. (2008) differentiate internal and external barriers, internal barriers consider lack of knowledge about this technology and limited business resources, the external aspects recognize as factors, the availability of external stakeholders and services for support and maintenance. In the area of internal barriers, it has been observed that features such as the training of entrepreneurs, favour the incorporation of the Internet (Barrera 2017), and that the barriers, lack of knowledge and resources are especially significant to

Copyright (C) 2019 The Authors. Published by VGTU Press.

This is an Open Access article distributed under the terms of the Creative Commons Attribution License (http://creativecommons.org/licenses/by/4.0/), which permits unrestricted use, distribution, and reproduction in any medium, provided the original author and source are credited.. 
dismiss the adoption of e-commerce in enterprises (Jones et al. 2003, Esmaeilpour et al. 2016).

In addition, previous research has shown that entrepreneurial motivation is related to specific behaviours that affect the commercial performance of an enterprise (Machmud and Sidharta 2016). In particular terms, Stephan et al. (2015) points out, after conducting a review of this topic, that entrepreneurial motivations affect areas such as: the performance of an organization, the strategic decisions of entrepreneurs to project their business, the investments that entrepreneurs make in their organization and the level of satisfaction with the business. A widely known typology is the denomination of motivation due to the need and search for opportunities (Amit and Muller 1995), this classification popularized by the Global Entrepreneurship (GEM) has been used in the last two decades.

Despite the recognized effect of entrepreneurial motivations, in areas such as investments, strategic decisions and commercial performance, there is a low understanding of the relationship of these motivations with the adoption of the Internet, the perception of barriers to using Internet and e-commerce, and the propensity towards e-commerce uses, such as sales, promotion and relationship with customers and suppliers. In a complementary way, it has been recognised that the analysis on Internet adoption in microenterprises is limited (Pascucci et al. 2017), since most of the research on adoption and use of the Internet is aimed at large, medium and small-sized enterprises. Faced with this knowledge gap, it is reasonable to propose the following research question: How are the motivations of microentrepreneurs linked to their perception of barriers to using Internet and the adoption of e-commerce in their ventures?

Additionally, the demographic conditions of microentrepreneurs and their enterprises in Latin America, have not been linked to perception of barrier to the Internet and specific uses of e-commerce. The demographic variables are an instrument for characterization of individuals widely used, these variables have the advantages of incorporating defined measurement scales, which are easy to understand and use, and the information they provide is simply transferable to other studies (Beane and Ennis 1987). Also, Denby (1989) has recommended the use of demography to form groups with different psychological characteristics, such as personal motivations.

In the field of SMEs, demographic variables have been extendenly used and are often combined with psychographic and cultural conditions, to achieve greater understanding of entrepreneurs' behavior. The relationship of aspects such as gender (Belás et al. 2015, Kozubíková et al. 2017, Orser and Riding 2018), age (Weber and Schaper 2004, Kickul et al. 2008, Matos et al. 2018), educational level (Laukkanen 2000, Wilson 2008, Liñán et al. 2016), marital status (Sirec and Mocnik 2010, Duman et al.
2015, Gupta and Mirchandani 2018), and participation in training (Liñán et al. 2016, Henry et al. 2017, Barrera 2017), have been linked to perceptions, motivations and attitudes in the field of entrepreneurship, consequently, the pertinence and timeliness of these variables is also recognized for the segmentation of entrepreneurs, in the field of e-commerce.

Accordingly, the objective of this research is to analyze if the motivations of micro-entrepreneur to undertake, are linked to the use of the Internet in his/her enterprise and the perception of barriers: absence of need, lack of awareness and lack of resources. Additionally, if the demographic conditions the micro-entrepreneur: age, gender, educational level, attendance to training sessions, and finally, the registration of the company, are linked to the use of the Internet in his/her enterprise and his/her perception of barriers mentioned. Entrepreneurial motivations chosen, due to their relevance in previous research are the following: family tradition, need and opportunity.

7,025 micro-enterprises are studied, which maintained entrepreneurial operations in place during 2017. The statistical methodology used considers logistic regressions, and Chi-square test for comparison of proportions in dichotomous qualitative variables, these methods have been widely used in previous investigations about entrepreneurship and SEMs. The analysis is presented for a total group of enterprises and is divided into: the Manufacturing industry and Agriculture, Forestry, Livestock and Fishing industry.

This information is considered relevant to support the development of micro-enterprises, whose owners show different motivations and demographic conditions, since the gaps in business performance, derived from obsolete technologies related to promotion, sale and product relationship, impact its permanence and development, and with it, the prosperity of families (Alburquerque Llorens 2004). It is considered that when traits of the entrepreneur and his/her company are discovered, which are related to the adoption and perception of Internet barriers, this facilitates the selection of microenterprises to provide support to them through counselling, assistance, training, subsidies and investment.

\section{Theoretical framework}

\subsection{ICTs and e-commerce in MSEMs}

Information and Communication Technologies, hereinafter referred to as ICTs, which are defined as software and hardware required by an enterprise to achieve its business objectives (Laudon and Laudon 2008), have been linked to various benefits in companies; in small and mediumsized enterprises, it has been estimated that ICTs increase both internal and external communication of an enterprise 
(Tarute and Gatautis 2014) and that they also strengthen communication with customers and suppliers (Alam and Noor 2009).

Regarding micro-enterprises from Ibero-America, there is limited research and the results are consistent with those obtained in small and medium-sized enterprises. It has been recognised that ICTs support the achievement of customer knowledge and the achievement of competitive advantages, since they imply increased performance through automation, access to information, reduction of transaction costs and development of learning (Saavedra García and Tapia Sánchez 2013); also, the use of ICTs has been positively related to innovation capacity in these enterprises (BenitoHernández et al. 2012).

With regard to the use of the Internet for marketing purposes, Rose et al. (1999) suggest that e-commerce provides opportunities for the development of personalised marketing and reduced contact with employees; while Espelt et al. (2000) acknowledge that the Internet is an important resource to promote products and distribute them to their customers. In small and medium-sized enterprises, the Internet is seen as a resource that allows them to compete with large companies (Mele 2013). In this sense, it has been pointed out that e-commerce supports the differentiation of products from small and medium-sized enterprises (SMEs) and the personalised relationship with their clients (Zwillenberg et al. 2014), and that it facilitates the market expansion and global distribution of products (Cecere and Cecere 2016).

Also, there is very little research associated with microenterprises from Ibero-America, evidencing the highest incomes of micro-entrepreneurs who are Internet users in Peru (Agüero and Pérez 2010), and a positive relationship between Internet adoption and productivity increase in microenterprises in that country (Huaroto 2012). It was also evidenced that the use of Internet allows for improvements in customer service and increases in sales in enterprises in Jalisco, Mexico (Cerón Bracamontes et al. 2018), and increases customer satisfaction and product sales in micro, small and medium-sized enterprises (MSMEs) in Spain (Blanco and Segarra-Oña 2014).

\subsection{Entrepreneurial motivations}

For decades, researchers have extensively searched to recognise the motivations that drive entrepreneurs to develop new businesses and the characteristics of entrepreneurs in relation to them. In the 1960s, McClelland (1961) proposed that the need for achievement is a central motivation for entrepreneurship; and, in the 1990s, Koh (1996) acknowledged that the desire for independence and achievement of autonomy are relevant motivations for creating new enterprises. Regarding studies on types of motivations for entrepreneurship, the duality of necessity and opportunity-based motivations has been widely validated since the beginning of the 21st century (Kirkwood 2009, Bosma and Levie 2009, Devins 2009). Necessity-based entrepreneurship involves running a business due to a lack of options or unfavourable work options, and opportunity-based entrepreneurship is associated with the pursuit of personal growth using business options. Amit and Muller (1995) have called necessity-based entrepreneurship "Push" and opportunity-based entrepreneurship "Pull".

The relationship between necessity and opportunitybased entrepreneurial motivations is linked to company performance. In this context, Zali et al. (2013) associate the growth of business with opportunity-based entrepreneurship in a positive manner while they associate the growth of business with necessity-based entrepreneurship in a negative manner. Acs and Varga (2005) point out that opportunity-based entrepreneurial motivation is linked to technological changes in the enterprise. Stephan et al. (2015) pose that opportunity-based entrepreneurship sustains its growth through innovation.

In Latin America, there are limited studies on necessity and opportunity-based entrepreneurial motivations. Thus, it has been suggested that, the frequency of necessity-based entrepreneurship is a majority and increasing group (Kantis et al. 2002, Rodríguez Ramírez 2008), that most of microentrepreneurs are motivated by necessity, they have little planning and training (Flores et al. 2016), and that there is a positive incidence of opportunity-based entrepreneurial motivation on the internationalisation of companies (García-Cabrera et al. 2018).

Although the classification of necessity and opportunity-based entrepreneurial motivations is acknowledged, more approaches on types of mobilisers towards entrepreneurship can be found. In a complementary way, Kuratko et al. (1997) recognises the following motivations: Extrinsic rewards, independence or autonomy, intrinsic rewards and family security. Furthermore, Yalcin and Kapu (2008) identify: Search for financial gain, social recognition, family tradition and independence.

Among the motivations indicated in these last classifications, family tradition has been positioned as a significant factor, since it has been indicated that it affects the creation of enterprises by generating reference models and restrictions (Frank et al. 2007). In Ibero-America, Cueva (2012) suggests that family tradition is one of the first causes for enterprise development in Spain, and Moreno (2013) shows that, in Spain, the intention to become an entrepreneur is higher among students with family members who have started their own enterprises.

Regarding entrepreneurship by family tradition, it has been recognized that rural entrepreneurs who develop their business by inheritance in countries such as India and China, and who are engaged in the development of 
handicrafts, have gaps in knowledge and resources for the adoption of e-commerce (Shah and Patel 2016, Huang et al. 2018); consequently, its organizations tend to be supported by government programs that encourage the development of e-commerce platforms.

It is concluded that necessity and opportunity-based entrepreneurial motivations, and motivation for entrepreneurship based on family tradition, are outstanding motivations that account for a propensity towards entrepreneurship in a context of micro and small-sized enterprises. Currently, only a few studies have analysed their incidence on micro-entrepreneurship, and there is no evidence, of a relationship between entrepreneurial motivations and the adoption of the Internet and perception of barriers in micro-entrepreneurship, which is consistent with the limited number of studies on this subject.

\subsection{Internal barriers for the adoption of ICTs and e-commerce}

Research developed in America, Europe and Asia, converge to identify internal barriers of enterprises that limit the use of ICTs and e-commerce. Causes have been mainly identified as the following: The belief that the Internet does not provide financial benefits to enterprises; lack of trained personnel to develop and maintain e-commerce systems; lack of infrastructure; high equipment and software costs; the belief that its profitability is insufficient with respect to the investment for its implementation; uncertainty about legal regulations; and fear about the safety of ICT users ( $\mathrm{Sin}$ Tan et al. 2010, Lawrence and Tar 2010).

In the field of small-sized enterprises, Alford and Page (2015) point out that the lack of staff knowledge and inability to measure their return on investment limit the implementation of ICTs and e-commerce. Likewise, Rahayu and Day (2015) state that the perception of benefits, organisational training for technology adoption, and the company owner's capacity for innovation, skills and experience in Information Technology, impact on the adoption of ecommerce in small-sized enterprises.

In Europe, the studies about ICT barriers in MSMEs also are scarce, it has been indicated that, in rural organisations in Sweden, barriers to the adoption of e-commerce are those already recognised in the context of larger enterprises (Sandberg and Håkansson 2014); this means that the lack of knowledge by employees, the lack of resources and the perception of lack of relevance of e-commerce in the business model are significant difficulties. As well, Arendt (2008) studies SMEs from Spain, Portugal and Poland, and they argue that the main barrier of better utilization of ICT and eBusiness in SMEs is not as much as lack of access to information technology, as it is the lack of proper knowledge, education and skilled owner-managers and employees within the enterprise. Gilmore et al. (2007) conclude that in SMEs of Northern Ireland, the lack of time, knowledge and financial resources, contribute to the development of deficient websites, which are not appreciated by customers. Additionally, Chatzoglou and Chatzoudes (2016), obtain as a result after studying SMEs in Greece, that the factors with greater incidence on the adoption of e-commerce in SMEs are, governmental support, consumer readiness, IT infrastructure and internet skills.

In the Latin American context, Nasco et al. (2008) recognise that the attitude of business managers is relevant for their willingness to incorporate e-commerce in small and medium-sized enterprises (SMEs). It has also been pointed out that the lack of resources in MSMEs is more evident due to the technological changes associated with ICTs (Jones et al. 2016). In Chile, Durán and Ignacio (2015) suggest that the associated costs and lack of knowledge by micro-entrepreneurs are the central causes for the dismissal of ICTs.

Taking into consideration the developed research in different countries and the different size of enterprises, converging towards equivalent barriers, it is concluded that the lack of competent employees (Arendt 2008), the financing requirements for investments and implementation costs (Johnson 2010), access to infrastructure, software and equipment (Harindranath et al. 2008) and the absence of perception of financial benefits or its contribution to the business model (Jones et al. 2003), are relevant difficulties that limit the adoption of ICTs and e-commerce in microenterprises, and these barriers are analyzed in this investigation.

\section{Methodology}

\subsection{Sample}

Data base included in the Fifth Micro-Entrepreneurship Survey of Chile, which evaluates 7,492 enterprises (Ministry of Economy, Development and Tourism of Chile n.d.) are analysed, in order to assess the relationship of the presented variables. The survey was applied from the second week of May to the first of August in 2017. A total of 7,492 people were interviewed in different regions of Chile. According to the statement of the Ministry of Economy, Development and Tourism of Chile (2016), micro-enterprises are small businesses employing 9 employees or fewer. Access to data and results is public.

The micro-entrepreneurs evaluated through a face-toface survey live in 13 regions of Chile, located in the north, centre, and south zones of this country. The sample frame of Fifth Micro-Entrepreneurship Survey of Chile (2018), is obtained from the National Survey of Employment, from this sampling frame, households and entrepreneurs were selected for evaluation through a face-to-face survey. The survey was applied in person, by interviewers distributed in blocks within cities in the 13 regions studied. A stratified 
sample was used, which represents all geographic areas and economic activities, considering their proportion in the sampling frame. The sample error that was obtained is $1.17 \%$.

Out of the total enterprises, 7,025 enterprises, which have entrepreneurial operations in place, are selected. In addition, the total sample is divided into manufacturing $(\mathrm{n}=969)$, and agricultural, livestock, forestry and fishing $(n=1,139)$ industries. These sectors have been chosen due to their significant contribution to the Gross Domestic Product in Chile, since the sum of both industries accounted for approximately $20.0 \%$ of GDP in 2016 (Banco Central de Chile - Central Bank of Chile n.d.).

\subsection{Statistic analysis}

Logistic regressions and Chi-squared tests were applied to obtain evidence, using statistical software STATA. Logistic regressions are applied in order to relate the demographic conditions of the entrepreneur, his/her motivations and registration of his/her company to Internet use and the barriers to adopt it; with the use of the Chi-square test, proportional variations in sales promotion, sales and relationship with customers and suppliers are assessed, depending on the entrepreneurial motivation: based on family tradition, necessity or opportunity-based motivations. The variables used to study the concepts are presented in Table 1 below.

Table 1. Used variables and measurement scale (source: variables extracted from Fifth Micro-Entrepreneurship Survey of the Ministry of Economy, Development and Tourism of Chile n.d.)

\begin{tabular}{|c|c|}
\hline Name of variable & $\begin{array}{c}\text { Response } \\
\text { alternatives }\end{array}$ \\
\hline Age & Ratio scale \\
\hline Gender & \multirow{15}{*}{$\begin{array}{l}\text { Dummy, } \\
\text { Yes }=1, \mathrm{No}=0\end{array}$} \\
\hline Primary education & \\
\hline Higher education & \\
\hline Married or living with a partner & \\
\hline Single & \\
\hline Divorced, separated, annulled & \\
\hline He/she attends training & \\
\hline $\mathrm{He} /$ she registers the enterprise with the IRS & \\
\hline $\begin{array}{l}\text { Entrepreneur motivated by (family) } \\
\text { tradition }\end{array}$ & \\
\hline Entrepreneur motivated by necessity & \\
\hline Entrepreneur motivated by opportunity & \\
\hline $\begin{array}{l}\mathrm{He} / \text { she uses the Internet in micro- } \\
\text { enterprise }\end{array}$ & \\
\hline $\begin{array}{l}\text { He/she uses the Internet to promote the } \\
\text { micro-enterprise }\end{array}$ & \\
\hline He/she uses the Internet to sell products & \\
\hline $\begin{array}{l}\mathrm{He} / \text { she uses the Internet to communicate } \\
\text { with clients and suppliers }\end{array}$ & \\
\hline
\end{tabular}

The entrepreneurial motivations and barriers to the adoption of e-Commerce, are selected for their relevance, which was justified in sections 1.2 and 1.3 in this investigation. Also, as indicated in the Introduction section, demographic variables are included as a complement to facilitate the segmentation of micro-entrepreneurs, due to the easy measurement of demographic variables and their complementation with psychological conditions.

The specific uses of the internet and e-commers that have been selected, are recognized as relevant in previous publications related to marketing and e-commerce (Singh 2002, Gómez and Gómez 2004, Sánchez 2012, Dueñas et al. 2018).

Logistic regressions are widely used to analyze the relationship between individual behaviors, expressed in nominal or dichotomous form, with nominal, ordinal, interval or reason variables, several researches, related to behaviors and perceptions of entrepreneurs and managers in smes, have used this method (Coleman 2000, Grilo and Thurik 2004, Arenius and Minniti 2005, Eniola 2018, Werner et al. 2018). The chi-square test is dominant in the study of differences in proportions in qualitative or dichotomous variables, also, it has been used frequently, in studies on entrepreneurs or management in smes (Messeghem 2003, O'regan et al. 2005, Grzegorz and Robert 2018, Belás et al. 2018). Due to the type of relations proposed between the variables, and the characteristics of scales of measurement in selected variables, the use of logistic regression and chi-square test as statistical analysis methods is justified.

For the total sample and industries selected, the following regression models have been obtained. Use of Internet in the enterprise and barriers to adopt it are considered as dependent variables: The Internet is not necessary; he/ she does not know how to use the Internet; he/she cannot afford to pay for Internet services. The opportunity-based entrepreneurial motivation was not included in order to avoid multicollinearity.

He/she uses the Internet $=\beta 0+\beta 1 \times$ Age $+\beta 2 \times$ Gender + $\beta 3 \times$ Primary E. $+\beta 4 \times$ Higher E. $+\beta 5 \times$ Married or living with a partner $+\beta 6 \times$ Single or divorced or annulled + $\beta 7 \times$ Attends training $+\beta 8 \times$ Registers the enterprise with the IRS $+\beta 9 \times$ Motivated by family tradition + $\beta 10 \times$ Motivated by necessity;

Internet is not necessary $=\beta 0+\beta 1 \times$ Age $+\beta 2 \times$ Gender + $\beta 3 \times$ Primary E. $+\beta 4 \times$ Higher E. $+\beta 5 \times$ Married or living with a partner $+\beta 6 \times$ Single or divorced or annulled + $\beta 7 \times$ Attends training $+\beta 8 \times$ Registers the enterprise with the IRS $+\beta 9 \times$ Motivated by family tradition + $\beta 10 \times$ Motivated by necessity; 
He/she does not know how to use the Internet $=\beta 0+$ $\beta 1 \times$ Age $+\beta 2 \times$ Gender $+\beta 3 \times$ Primary E. $+\beta 4 \times$ Higher E. $+\beta 5 \times$ Married or living with a partner $+\beta 6 \times$ Single or divorced or annulled $+\beta 7 \times$ Attends training $+\beta 8 \times$ Registers the enterprise with the IRS $+\beta 9 \times$ Motivated by family tradition $+\beta 10 \times$ Motivated by necessity;

He/she cannot afford to pay for Internet $=\beta 0+\beta 1 \times$ Age + $\beta 2 \times$ Gender $+\beta 3 \times$ Primary E. $+\beta 4 \times$ Higher E. $+\beta 5 \times$ Married or living with a partner $+\beta 6 \times$ Single or divorced or annulled $+\beta 7 \times$ Attends training $+\beta 8 \times$ Registers the enterprise with the IRS $+\beta 9 \times$ Motivated by family tradition $+\beta 10 \times$ Motivated by necessity.

\section{Results}

\subsection{Demographic characteristics according to motivation}

Characteristics of the entrepreneur classified according to the entrepreneurial motivation group are described in Table 2. From the results, it is shown that average age, percentage of men and primary education, as the highest level attained, are higher in entrepreneurs motivated by family tradition. Also, it is observed that entrepreneurs motivated by necessity include a higher proportion of women and a lower age average. Finally, it can be observed that entrepreneurs motivated by opportunity are married and they have reached Higher Education studies in a higher degree.

Percentages of Internet adoption and barriers to adopt it are analysed in Table 3. It can be observed that Internet use is lower in the agriculture, forestry, livestock and fishing industries and that lack of knowledge is the main cause of it. The highest percentage of use of the Internet can be found in the manufacturing industry and lack of knowledge is the main cause to dismiss it.

\subsection{Model 1: Incident variables for the adoption and barriers of the Internet}

When performing linear regressions to relate explanatory variables selected for operational modernity in the total sample and in groups representing the sizes of enterprises and industries, Model 1 results are obtained and presented in Table 4. A multicollinearity analysis was performed on the variables and no evidence of this condition was found. Also, a Chi-square statistic lower than 0.01 was obtained; therefore, variables are considered valid with a $99 \%$ CI.

The results included in Table 4 indicate that all regression coefficients are significant for Internet use in the enterprise, except for the single marital status. It is observed that, with a $99 \% \mathrm{CI}$, entrepreneurs with higher education studies $(\mathrm{OR}=4.882 ; \mathrm{P}=0.00)$, attendance to training $(\mathrm{OR}=$ $1.964 ; \mathrm{P}=0.00)$, and registration of the enterprise with the IRS ( $\mathrm{OR}=3.040 ; \mathrm{P}=0.00)$, are related to an increased use of the Internet in micro-enterprises. Conversely, age $(\mathrm{OR}=$ $0.949 ; \mathrm{P}=0.00$ ), entrepreneur motivated by family tradition $(\mathrm{OR}=0.428 ; \mathrm{P}=0.00)$ and by necessity $(\mathrm{OR}=0.807 ; \mathrm{P}=$ 0.00 ) affect its adoption in a negative manner with a $99 \%$ CI. Male gender $(\mathrm{OR}=1.165 ; \mathrm{P}=0.02)$, the married marital status or living with a partner $(\mathrm{OR}=1.510 ; \mathrm{P}=0.04)$, and divorced, separated and annulled ( $\mathrm{OR}=1.482 ; \mathrm{P}=0.06)$, also show a positive relation with a $95 \%$ or $90 \% \mathrm{CI}$.

Regarding the incidence of the studied variables with dismissal of Internet use since it is considered unnecessary for micro-enterprises, the obtained results indicate that entrepreneurs with higher education studies $(\mathrm{OR}=1.666$; $\mathrm{P}$ $=0.00)$ and the registration of the enterprise with the IRS $(\mathrm{OR}=1.326 ; \mathrm{P}=0.00)$, are positively related with this cause with a $99 \%$ CI. On the contrary, entrepreneurs who are older $(\mathrm{OR}=0.952 ; \mathrm{P}=0.00)$, with higher education studies $(\mathrm{OR}=0.451 ; \mathrm{P}=0.00)$ and motivated by family tradition $(\mathrm{OR}=0.753 ; \mathrm{P}=0.00)$, imply less propensity to dismiss Internet use due to this cause with a $99 \%$ CI. The findings indicate that the dismissal of the Internet attributes is higher

Table 2. Demographic conditions according to entrepreneurial motivation (source: own elaboration)

\begin{tabular}{|l|c|c|c|c|c|c|}
\hline & Frequency & Average age & Male \% & $\begin{array}{c}\text { Primary } \\
\text { Education \% }\end{array}$ & $\begin{array}{c}\text { Higher } \\
\text { Education\% }\end{array}$ & $\begin{array}{c}\text { Married \% } \\
\text { Family tradition }\end{array}$ \\
\hline Necessity & 1.883 & 54.86 & $71.1 \%$ & $45.56 \%$ & $11.50 \%$ & $60.75 \%$ \\
\hline Opportunity & 3.926 & 51.22 & $63.17 \%$ & $29.64 \%$ & $23.11 \%$ & $60.28 \%$ \\
\hline
\end{tabular}

Table 3. Adoption and barriers of the Internet in selected industries (source: own elaboration)

\begin{tabular}{|l|c|c|c|c|c|c|}
\hline & $\begin{array}{c}\text { Frequency } \\
\text { Total }\end{array}$ & $\begin{array}{c}\text { Internet } \\
\text { Use } \%\end{array}$ & $\begin{array}{c}\text { No use } \\
\text { frequency }\end{array}$ & $\begin{array}{c}\text { Not necessary } \\
\%\end{array}$ & $\begin{array}{c}\text { Lack of } \\
\text { knowledge } \%\end{array}$ & $\begin{array}{c}\text { Lack of } \\
\text { resources \% }\end{array}$ \\
\hline Manufacture & 969 & $46.44 \%$ & 498 & $40.96 \%$ & $43.98 \%$ & $9.04 \%$ \\
\hline Agriculture & 1.139 & $14.84 \%$ & 916 & $25.87 \%$ & $62.88 \%$ & $5.79 \%$ \\
\hline
\end{tabular}


Table 4. Adoption and barriers of the Internet in the total sample (source: own elaboration)

\begin{tabular}{|c|c|c|c|c|c|c|c|c|}
\hline & \multicolumn{2}{|c|}{$\begin{array}{l}\text { Use of Internet } \\
\quad(n=6,930)\end{array}$} & \multicolumn{2}{|c|}{$\begin{array}{l}\text { Unnecessary for micro- } \\
\text { enterprise }(n=3,961)\end{array}$} & \multicolumn{2}{|c|}{$\begin{array}{l}\text { Does not know how to } \\
\text { use the Internet } \\
(n=3,960)\end{array}$} & \multicolumn{2}{|c|}{$\begin{array}{c}\text { Cannot afford to pay for } \\
\text { the Internet } \\
(n=3,960)\end{array}$} \\
\hline & \multicolumn{2}{|c|}{$\mathrm{P}>\mathrm{Chi}$-squared $=0.00$} & \multicolumn{2}{|c|}{$\mathrm{P}>$ Chi-squared $=0.00$} & \multicolumn{2}{|c|}{$\mathrm{P}>$ Chi-squared $=0.00$} & \multicolumn{2}{|c|}{$\mathrm{P}>$ Chi-squared $=0.00$} \\
\hline & OR & $\mathrm{P}>|\mathrm{z}|$ & OR & $\mathrm{P}>|\mathrm{z}|$ & OR & $\mathrm{P}>|\mathrm{z}|$ & OR & $\mathrm{P}>|\mathrm{z}|$ \\
\hline Age & 0.949 & $0.00^{\star * *}$ & 0.952 & $0.00^{* * *}$ & 1.058 & $0.00^{* * *}$ & 0.991 & $0.08^{*}$ \\
\hline Gender & 1.165 & $0.02^{\star *}$ & 0.953 & 0.52 & 1.171 & $0.03^{* *}$ & 0.718 & $0.01^{* * *}$ \\
\hline Primary Education & 0.261 & $0.00^{* * *}$ & 0.451 & $0.00^{* * *}$ & 2.177 & $0.00^{* * *}$ & 1.095 & 0.50 \\
\hline Higher Education & 4.882 & $0.00^{* * *}$ & 1.666 & $0.00^{* * *}$ & 0.468 & $0.00^{\star * *}$ & 0.888 & 0.66 \\
\hline $\begin{array}{l}\text { Married or living with a } \\
\text { partner }\end{array}$ & 1.510 & $0.04^{\star *}$ & 1.379 & $0.05^{\star}$ & 0.860 & 0.33 & 0.930 & 0.80 \\
\hline Single & 1.080 & 0.71 & 1.144 & 0.46 & 0.779 & 0.14 & 1.292 & 0.40 \\
\hline $\begin{array}{l}\text { Divorced, separated, } \\
\text { annulled }\end{array}$ & 1.482 & $0.06^{*}$ & 1.329 & 0.13 & 0.758 & 0.12 & 1.025 & 0.93 \\
\hline He/she attends training & 1.964 & $0.00^{* * *}$ & 0.968 & 0.74 & 1.002 & 0.97 & 1.172 & 0.35 \\
\hline $\begin{array}{l}\text { He/she registers the } \\
\text { enterprise with the IRS }\end{array}$ & 3.040 & $0.00^{* * *}$ & 1.326 & $0.00^{* * *}$ & 0.819 & $0.01^{\star *}$ & 0.788 & 0.10 \\
\hline $\begin{array}{l}\text { Entrepreneur motiva- } \\
\text { ted by family tradition }\end{array}$ & 0.428 & $0.00^{* * *}$ & 0.753 & $0.00^{* * *}$ & 1.379 & $0.00^{* *}$ & 0.958 & 0.82 \\
\hline $\begin{array}{l}\text { Entrepreneur motivated } \\
\text { by necessity }\end{array}$ & 0.807 & $0.00^{* * *}$ & 0.982 & 0.83 & 0.919 & 0.31 & 1.427 & $0.01^{\star *}$ \\
\hline Constant & 3.640 & 0.85 & 11.473 & $0.00^{* * *}$ & 0.027 & $0.00^{* * *}$ & 0.125 & $0.00^{* * *}$ \\
\hline
\end{tabular}

Note: ${ }^{* * *}$ Significance of regression coefficient with a $99 \%$ CI ${ }^{*}$ Significance of regression coefficient with a $95 \%$ CI, * Significance of regression coefficient with a $90 \% \mathrm{CI}$.

in entrepreneurs with higher education studies and who are younger. As a hypothesis, it is stated that knowledge and resources for Internet adoption are available in this group, however, benefits of the Internet in commercial and productive terms are not identified because entrepreneurs lack training and experience to use it as a support resource in their businesses.

Regarding the absence of Internet in enterprises due to lack of knowledge, age $(\mathrm{OR}=1.058 ; \mathrm{P}=0.00)$, primary education $(\mathrm{OR}=2.177 ; \mathrm{P}=0.00)$ and entrepreneurial motivation based on family tradition $(\mathrm{OR}=1.379 ; \mathrm{P}=0.00)$ show a positive relationship with this cause with a $99 \% \mathrm{CI}$. Male gender $(\mathrm{OR}=1.171 ; \mathrm{P}=0.03)$, also shows a positive link with a $95 \% \mathrm{CI}$. Conversely, higher education studies (OR = $0.468 ; \mathrm{P}=0.00)$ and the registration of the enterprise with the IRS ( $\mathrm{OR}=0.819 ; \mathrm{P}=0.01$ ) have a negative relationship with lack of knowledge with a $99 \%$ and $95 \% \mathrm{CI}$, respectively. The obtained evidence recognises that entrepreneurs who are older, with a greater family tradition, and less education and formality, tend, to a greater extent, to see this difficulty.

In turn, lack of resources is associated with $99 \%$ CI with female gender $(\mathrm{OR}=0.718 ; \mathrm{P}=0.01)$, entrepreneur motivated by necessity $(\mathrm{OR}=1.427 ; \mathrm{P}=0.01)$ with a $95 \%$ $\mathrm{CI}$, and entrepreneurs who are younger $(\mathrm{OR}=0.991 ; \mathrm{P}=$ 0.08 ) with a $90 \%$ CI. These results are consistent, because the lack of resources is more pronounced in young, female entrepreneurs who run micro-enterprises due to lack of job opportunities or who cannot be employed as a dependent employee in an enterprise.

In relation to adoption of the Internet, the greatest Odds Ratios obtained are: higher education and registration of the enterprise with the IRS. On the contrary, the lowest Odds Ratio is entrepreneur motivated by family tradition; consequently, the relevance of these variables in Internet adoption is highlighted. Additionally, in relation to the lack of knowledge cause, entrepreneurs motivated by family tradition and who have achieved primary education studies as the highest educational level are emphasised; while for the lack of resources cause, entrepreneurs motivated by necessity is emphasised.

The analysis performed on the manufacturing industry, as shown in Table 5, demonstrates results consistent with those previously exposed. In this group, the married marital status or living with a partner $(\mathrm{OR}=3.251 ; \mathrm{P}=0.00)$ and divorced, separated or annulled $(\mathrm{OR}=3.281 ; \mathrm{P}=0.00)$ registration of the enterprise with the IRS $(\mathrm{OR}=3.547 ; \mathrm{P}=0.00)$ are identified due to their high Odds Ratio, greater than 1 in the linear regression associated with the adoption of the Internet, which implies a positive relationship between the variables; conversely, entrepreneurs motivated by family tradition show a relevant negative effect $(\mathrm{OR}=0.357 ; \mathrm{P}=$ 0.00 ) and a $99 \%$ CI.

Finally, the results of micro-enterprises whose economic activity is agriculture, forestry, livestock and fisheries are shown in Table 6. In this group, age $(\mathrm{OR}=0.950 ; \mathrm{P}=0.00)$ 
Table 5. Adoption and barriers of the Internet in the manufacturing industry (source: own elaboration)

\begin{tabular}{|c|c|c|c|c|c|c|c|c|}
\hline & \multicolumn{2}{|c|}{$\begin{array}{l}\text { Use of Internet } \\
\quad(n=1,969)\end{array}$} & \multicolumn{2}{|c|}{$\begin{array}{c}\text { Unnecessary } \\
\text { for micro-enterprise } \\
(n=491)\end{array}$} & \multicolumn{2}{|c|}{$\begin{array}{l}\text { Does not know how to } \\
\text { use the Internet } \\
(n=491)\end{array}$} & \multicolumn{2}{|c|}{$\begin{array}{l}\text { Cannot afford to pay } \\
\text { for the Internet } \\
(n=491)\end{array}$} \\
\hline & \multicolumn{2}{|c|}{$\mathrm{P}>$ Chi-squared $=0.00$} & \multicolumn{2}{|c|}{$\mathrm{P}>$ Chi-squared $=0.00$} & \multicolumn{2}{|c|}{$\mathrm{P}>$ Chi-squared $=0.00$} & \multicolumn{2}{|c|}{$\mathrm{P}>$ Chi-squared $=0.00$} \\
\hline & OR & $\mathrm{P}>|\mathrm{z}|$ & OR & $\mathrm{P}>|\mathrm{z}|$ & OR & $\mathrm{P}>|\mathrm{z}|$ & OR & $\mathrm{P}>|\mathrm{z}|$ \\
\hline Age & 0.940 & $0.00^{* * *}$ & 0.957 & $0.00^{* * *}$ & 1.067 & $0.00^{* * *}$ & 0.982 & 0.16 \\
\hline Gender & 0.960 & 0.82 & 1.101 & 0.63 & 0.901 & 0.63 & 1.137 & 0.71 \\
\hline Primary education & 0.212 & $0.00^{* * *}$ & 0.465 & $0.00^{* * *}$ & 2.335 & $0.00^{* * *}$ & 0.841 & 0.61 \\
\hline Higher education & 2.553 & $0.00^{* * *}$ & 1.287 & 0.47 & 0.905 & 0.80 & 0.426 & 0.26 \\
\hline $\begin{array}{l}\text { Married or living with a } \\
\text { partner }\end{array}$ & 3.251 & $0.01^{\star *}$ & 1.621 & 0.24 & 0.825 & 0.61 & 1.094 & 0.89 \\
\hline Single & 1.780 & 0.26 & 1.214 & 0.67 & 0.633 & 0.29 & 1.817 & 0.40 \\
\hline $\begin{array}{l}\text { Divorced, separated, } \\
\text { annulled }\end{array}$ & 3.281 & $0.02^{* *}$ & 2.485 & $0.04^{* *}$ & 0.543 & 0.17 & 0.536 & 0.47 \\
\hline $\mathrm{He} /$ she attends training & 1.464 & $0.04^{\star *}$ & 1.064 & 0.81 & 1.082 & 0.77 & 0.648 & 0.36 \\
\hline $\begin{array}{l}\text { He/she registers the } \\
\text { enterprise with the IRS }\end{array}$ & 3.547 & $0.00^{* * *}$ & 1.016 & 0.94 & 0.833 & 0.49 & 0.742 & 0.51 \\
\hline $\begin{array}{l}\text { Entrepreneur motivated by } \\
\text { family tradition }\end{array}$ & 0.357 & $0.00^{* * *}$ & 0.469 & $0.02^{* *}$ & 1.710 & $0.09^{*}$ & 2.285 & $0.06^{\star}$ \\
\hline $\begin{array}{l}\text { Entrepreneur motivated by } \\
\text { necessity }\end{array}$ & 0.858 & 0.39 & 0.824 & 0.40 & 1.011 & 0.96 & 2.230 & $0.03^{* *}$ \\
\hline Constant & 5.425 & $0.00^{* * *}$ & 6.99 & $0.00^{* * *}$ & 0.017 & $0.00^{* * *}$ & 0.044 & $0.00^{* * *}$ \\
\hline
\end{tabular}

Note: ${ }^{* *}$ Significance of regression coefficient with a $99 \%$ CI, ${ }^{* *}$ Significance of regression coefficient with a $95 \%$ CI, ${ }^{*}$ Significance of regression coefficient with a $90 \% \mathrm{CI}$.

Table 6. Adoption and barriers of the Internet in agriculture, forestry, livestock, fishing industries (source: own elaboration)

\begin{tabular}{|c|c|c|c|c|c|c|c|c|}
\hline & \multicolumn{2}{|c|}{$\begin{array}{l}\text { Use of Internet } \\
\quad(n=1,969)\end{array}$} & \multicolumn{2}{|c|}{$\begin{array}{c}\text { Unnecessary } \\
\text { for micro-enterprise } \\
(n=909)\end{array}$} & \multicolumn{2}{|c|}{$\begin{array}{l}\text { Does not know how to } \\
\text { use the Internet } \\
(n=909)\end{array}$} & \multicolumn{2}{|c|}{$\begin{array}{l}\text { Cannot afford to pay } \\
\text { for the Internet } \\
\quad(n=909)\end{array}$} \\
\hline & \multicolumn{2}{|c|}{$\mathrm{P}>$ Chi-squared $=0.00$} & \multicolumn{2}{|c|}{$\mathrm{P}>$ Chi-squared $=0.00$} & \multicolumn{2}{|c|}{$\mathrm{P}>$ Chi-squared $=0.00$} & \multicolumn{2}{|c|}{$\mathrm{P}>\mathrm{Chi}$-squared $=0.00$} \\
\hline & OR & $\mathrm{P}>|\mathrm{z}|$ & OR & $\mathrm{P}>|\mathrm{z}|$ & OR & $\mathrm{P}>|\mathrm{z}|$ & OR & $\mathrm{P}>|\mathrm{z}|$ \\
\hline Age & 0.950 & $0.00^{\star * *}$ & 0.955 & $0.00^{\star * \star}$ & 1.055 & $0.00^{\star * *}$ & 0.955 & $0.00^{* * *}$ \\
\hline Gender & 1.084 & 0.74 & 0.820 & 0.31 & 1.167 & 0.39 & 0.941 & 0.86 \\
\hline Primary education & 0.270 & $0.00^{\star * *}$ & 0.478 & $0.00^{* * *}$ & 2.020 & $0.00^{* * *}$ & 1.316 & 0.41 \\
\hline Higher education & 4.111 & $0.00^{\star * *}$ & 1.289 & 0.58 & 0.298 & $0.02^{* *}$ & 1.293 & 0.75 \\
\hline $\begin{array}{l}\text { Married or living with a } \\
\text { partner }\end{array}$ & 0.620 & 0.41 & 1.248 & 0.62 & 1.501 & 0.24 & 0.219 & $0.00^{* * *}$ \\
\hline Single & 0.521 & 0.29 & 1.806 & 0.23 & 1.009 & 0.98 & 0.389 & 0.12 \\
\hline $\begin{array}{l}\text { Divorced, separated, } \\
\text { annulled }\end{array}$ & 0.310 & 0.10 & 1.047 & 0.81 & 0.949 & 0.90 & 0.177 & $0.05^{\star}$ \\
\hline $\mathrm{He} /$ she attends training & 2.050 & $0.00^{\star * *}$ & 1.180 & 0.44 & 0.913 & 0.61 & 1.699 & 0.11 \\
\hline $\begin{array}{l}\text { He/she registers the } \\
\text { enterprise with the IRS }\end{array}$ & 4.251 & $0.00^{* * *}$ & 1.085 & 0.65 & 0.958 & 0.83 & 1.411 & 0.38 \\
\hline $\begin{array}{l}\text { Entrepreneur motivated by } \\
\text { family tradition }\end{array}$ & 0.452 & $0.00^{* * *}$ & 1.085 & 0.65 & 1.078 & 0.65 & 0.689 & 0.30 \\
\hline $\begin{array}{l}\text { Entrepreneur motivated by } \\
\text { necessity }\end{array}$ & 0.654 & 0.132 & 0.880 & 0.56 & 0.979 & 0.91 & 1.689 & 0.12 \\
\hline Constant & 3.707 & $0.08^{\star}$ & 6.261 & $0.00^{* * *}$ & 0.037 & $0.00^{* * *}$ & 1.760 & 0.54 \\
\hline
\end{tabular}

Note: ${ }^{* *}$ Significance of regression coefficient with a $99 \%$ CI, ${ }^{* *}$ Significance of regression coefficient with a $95 \%$ CI, ${ }^{*}$ Significance of regression coefficient with a $90 \%$ CI. 
shows a negative relationship with the adoption of the Internet and with selected barriers with a 99\% CI; primary education is also recognised as a significant condition, and it has a negative relationship with the adoption of the Internet $(\mathrm{OR}=0.270 ; \mathrm{P}=0.00)$, lack of need for Internet in the enterprise $(\mathrm{OR}=0.478 ; \mathrm{P}=0.00)$, and a positive relationship with he/she does not know how to use the Internet $(\mathrm{OR}=$ $2.020 ; \mathrm{P}=0.00$ ), with a $99 \% \mathrm{CI}$, is observed. The results are similar to those obtained in linear regressions of the total sample. As a distinctive finding, it is recognised that the married marital status or living with a partner $(\mathrm{OR}=0.219$; $\mathrm{P}=0.00)$, entrepreneurs who are older $(\mathrm{OR}=0.955 ; \mathrm{P}=$ 0.00 ), with a $99 \% \mathrm{CI}$, and marital status divorced, separated or annulled ( $\mathrm{OR}=0.177 ; \mathrm{P}=0.05)$, with a $95 \% \mathrm{CI}$, decrease the propensity to dismiss the adoption of the Internet due to lack of resources. Regarding gender, no statistically significant differences in relation to the use of the Internet and the perception of barriers are observed.

\subsection{Model 2: Entrepreneurial motivation and uses of the Internet}

The analysis of proportions using the Chi-square test, as shown in Table 7, exhibits a lower propensity to promote products on the Internet $(\mathrm{P}=0.00 ; 99 \% \mathrm{CI})$, sales on the Internet $(\mathrm{P}=0.01 ; 95 \% \mathrm{CI})$ and relationship with customers and suppliers $(\mathrm{P}=0.00 ; 99 \% \mathrm{CI})$, if compared to entrepreneurs motivated by family tradition engaging in economic activities independently. In addition, it is observed that promotion on the Internet is higher in entrepreneurs motivated by necessity $(\mathrm{P}=0.03 ; 95 \% \mathrm{CI})$. In the case of entrepreneurs motivated by opportunity, no differences are observed.

Furthermore, a logistic regression analysis is performed, which considers the entrepreneurial motivation as independent variables and the uses given to the Internet as dependent variables. Evidence shown in Table 8, shows a negative association between entrepreneurs motivated by family tradition and promotion of the enterprise with a 99\% CI; conversely, necessity and opportunity-based motivations

Table 7. Entrepreneurial motivation and uses of the Internet in the total sample (source: own elaboration)

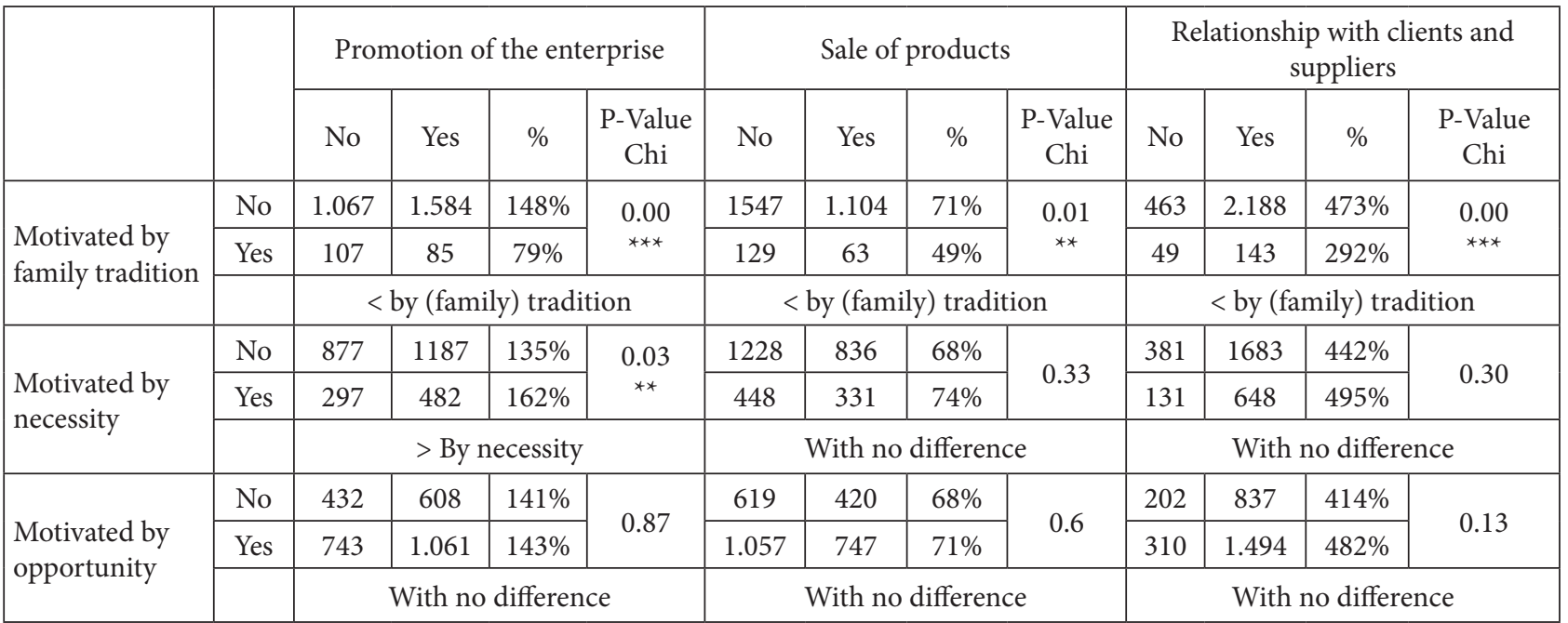

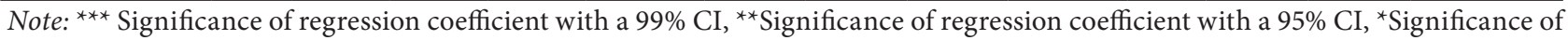
regression coefficient with a $90 \% \mathrm{CI}$.

Table 8. Entrepreneurial motivation and uses of the Internet in the total sample (source: own elaboration)

\begin{tabular}{|l|c|c|c|c|c|c|}
\hline \multirow{4}{*}{} & $\begin{array}{c}\text { Promotion of the enterprise } \\
(n=2843)\end{array}$ & \multicolumn{2}{|c|}{$\begin{array}{c}\text { Sale of products } \\
(n=2843)\end{array}$} & $\begin{array}{c}\text { Relationship with clients and } \\
\text { suppliers }(n=2843)\end{array}$ \\
\cline { 2 - 7 } & $\mathrm{P}>$ Chi-squared $=0.00$ & \multicolumn{2}{|c|}{$\mathrm{P}>$ Chi-squared $=0.00$} & \multicolumn{2}{|c|}{$\mathrm{P}>$ Chi-squared $=0.00$} \\
\cline { 2 - 7 } & OR & $\mathrm{P}>|\mathrm{z}|$ & $\mathrm{OR}$ & $\mathrm{P}>|\mathrm{z}|$ & $\mathrm{OR}$ & $\mathrm{P}>|\mathrm{z}|$ \\
\hline Motivated by family tradition & 0.523 & $0.02^{* *}$ & 0.788 & 0.41 & 1.395 & 0.27 \\
\hline Motivated by necessity & 1.068 & 0.79 & 1.193 & 0.49 & 2.365 & $0.00^{* * *}$ \\
\hline Motivated by family tradition & 0.940 & 0.80 & 1.141 & 0.60 & 2.304 & $0.00^{* * *}$ \\
\hline Constant & 1.518 & 0.92 & 0.619 & $0.05^{*}$ & 2.090 & $0.00^{* * *}$ \\
\hline
\end{tabular}

Note: ${ }^{* *}$ Significance of regression coefficient with a $99 \%$ CI, ${ }^{* *}$ Significance of regression coefficient with a $95 \%$ CI, ${ }^{*}$ Significance of regression coefficient with a $90 \%$ CI. 
are positively linked with the relationship between enterprises, customers and suppliers with a 99\% CI. Also, a multicollinearity analysis between the variables is carried out without finding any evidence. The Chi-square statistics equal to 0.000 validate the developed models.

The results obtained through logistic regressions and Chi-squared tests, consistently express differences in perception of barriers to Internet adoption and use of the Internet regarding specific activities, based on entrepreneurial motivations and demographic conditions such as age, gender and educational level of micro-entrepreneurs. In logistic regression analysis, oddratios statistically significant with $95 \%$ ( $\mathrm{p}<0.05)$ or $99 \%(\mathrm{p}<0.01)$ confidence, represent positive effect if its value is greater than 1 and negative if its magnitude is less than 1 . Also, the developed regressions present validity as contructs, obtaining magnitudes $\mathrm{P}>\mathrm{Chi}$ squared $=0.00$.

\section{Conclusions and implications}

The evidence obtained, extend the knowledge about the use of e-commerce in micro-enterprises, in particular terms, these allow understanding the relationship of conditions in micro-entrepreneurs with their perception of barriers to Internet and the uses of e-commerce in their organizations. In specific terms, it is recognized that the personal motivations to develop a micro-enterprise, and also some demographic conditions in micro-entrepreneurs, are linked to the recognition of barriers to the use of Internet, and the propensity towards specific uses of e-commerce.

The obtained findings show that entrepreneurs motivated by necessity and with primary education, tend to minimise the use of the Internet in micro-enterprises. The results are consistent with previous research, which indicates a lower use of internet in companies led by people who achieved a lower level of education (Liñán et al. 2016), also, with the link of entrepreneurship by necessity and tradition and less openness to new risks or learnings (Flores et al. 2016), which would affect their ability to adopt the internet.

The dismissal of the Internet since it is perceived as unnecessary, is negatively associated with entrepreneurs motivated by family tradition and primary education. Furthermore, the dismissal of the adoption of the Internet due to lack of knowledge shows an association with entrepreneurs motivated by family tradition, who are older, male, with primary education. These findings are consistent with previous publications which link motivation by tradition (Shah and Patel 2016, Huang et al. 2018), low educational levels (Laukkanen 2000, Wilson 2008), and older entrepreneurs (Wilson et al. 2008, Matos et al. 2018), with lack of knowledge or resources to implement e-commerce.

In relation to the incidence of entrepreneurs motivated by family tradition, it is hypothesised that micro-entrepreneurs in these businesses tend to learn their jobs from their parents or grandparents and, therefore, are more reluctant to change, and that these conditions have a greater impact on the adoption and use of the Internet in enterprises when micro-entrepreneurs are properly trained to develop judgments about this technology.

Also, lack of resources is linked to female entrepreneurs who are younger and motivated by necessity, this result is consistent with previous publications, which indicate inequity of access to resources by female entrepreneurs who are enterprising due to lack of money (Orser and Riding 2018, Yu and Cui 2019). Regarding the result that points out that in married or couple micro-entrepreneurs there are lack of resources for the adoption of e-commerce, previously, it has been recognized that families with a partner and children tend to lack financial resources, for the expenses involved in the maintenance of their homes (Acs 2005).

The high importance of training for the adoption of the Internet and perception of barriers to dismiss it is also emphasised, which is consistent with previous findings (Teo 2001, Platero-Jaime et al. 2017). Again, it is identified that the fact of completing basic and superior educational levels and attending training courses is crucial for incorporating the Internet in enterprises and, thus, their competitiveness. Finally, it has been suggested that the formalization of small and medium enterprises facilitates the development of these organizations (Anderson 2017), which is coherent with the positive relationship between formalization with the IRS and e-commerce that has been obtained.

Finally, the sale of products through the web, does not show a relationship with micro-entrepreneur's motivations. As a hypothesis, regardless of the type of motivation of micro-entrepreneurs, it is proposed that selling products on the Internet requires technological support such as a registration and payment system and support technologies in input and output logistics systems, considering the classification of the Value Chain (Porter 1980).

As a practical implications of the results obtained, it is suggested that it is relevant to use the evidence to strengthen the use of the Internet, through directed actions according to conditions studied in micro-entrepreneurs, under the support of programs with government or private funding. In line with Pessoa de Matos and Arroio (2011) and De Sena (2014), it is proposed that it is favourable to implement interventions differentiated by age, educational level and entrepreneurial motivation.

In particular terms, to prioritise micro-entrepreneurs with primary education as the highest level achieved, who have not registered their enterprises with the IRS and who are motivated by family tradition and necessity, in order to provide them training, advice and financial resources, allowing them to know the use of the Internet and access it with financing. In a complementary way, to support younger micro-entrepreneurs, with a higher educational level and 
who have registered their enterprises, have received training and advice allowing them to recognise the benefits of adopting the Internet in their enterprises and strategies for commercial use.

\section{Limitations and future investigations}

The design of the study is correlational, cross-sectional, and no longitudinal or experimental analyses have been considered to determine with greater robustness causeeffect relationships between the variables. In future research, the use of control groups in geographic zones could show differences derived from industrial and geographical contexts; also, the application of interviews with qualitative guidance would support the understanding of underlying internal processes. Despite the limitations described, it is estimated that the high number of cases studied, and the control carried out by industry groups, allows us to validate the relationships we have found. In addition, the analysis of motivation is made through a correlation and regression matrix, in which coherent findings are obtained.

Also, future studies could use longitudinal research design, in order to evaluate over time, the effects of e-commerce on income, profits and profitability, in organizations led by micro-entrepreneurs motivated by opportunity, need or family tradition, and with specifics demographic conditions. This information would allow to recognize the financial effects of motives in micro-entrepreneurs. That is, such evidence would reveal the financial, economic and social impact of the adoption of e-commerce, and facilitate the obtaining of resources to intervene through financing, subsidies or training, to support microentrepreneurs with unfavourable conditions for the use of these technologies.

\section{References}

Acs G (2005) Working to make ends meet: understanding the income and expenses of America's low-income families. The Urban Institute, Assessing the New Federalism Project, Washington, DC.

Acs ZJ, Varga A (2005) Entrepreneurship, agglomeration and technological change. Small business economics 24 (3): 323 334. https://doi.org/10.1007/s11187-005-1998-4

Agüero A, Pérez P (2010) El uso de Internet de los trabajadores independientes y microempresarios en el Perú. In: Investigación presentada en la Conferencia ACORN-REDECOM.

Alam SS, Noor MKM (2009) ICT adoption in small and medium enterprises: An empirical evidence of service sectors in Malaysia. International Journal of Business and management 4 (2): 112. https://doi.org/10.5539/ijbm.v4n2p112

Alburquerque Llorens F (2004) Desarrollo económico local y descentralización en América Latina. Revista de la CEPAL. https://doi.org/10.18356/5a9b65f3-es

Alford P, Page SJ (2015) Marketing technology for adoption by small business. The Service Industries Journal 35 (11-12): 655-669. https://doi.org/10.1080/02642069.2015.1062884
Amit R, Muller E (1995) "Push" and "pull" entrepreneurship. Journal of Small Business \& Entrepreneurship 12 (4): 64-80. https://doi.org/10.1080/08276331.1995.10600505

Anderson W (2017) Factors affecting small \& medium enterprises (SMEs) start-up and growth in Tanzania. Pan-African Journal of Business Management 1 (1): 1-26.

Arendt L (2008) Barriers to ICT adoption in SMEs: how to bridge the digital divide? Journal of Systems and Information Technology 10 (2): 93-108. https://doi.org/10.1108/13287260810897738

Arenius P, Minniti M (2005) Perceptual variables and nascent entrepreneurship. Small business economics 24 (3): 233-247. https://doi.org/10.1007/s11187-005-1984-x

Banco Central de Chile (n.d.). Cuentas Nacionales de Chile: Evolución de la actividad económica tercer trimestre de 2017 www.bcentral.cl/documents/20143/32019/CuentasNacionales_tercer_trimestre2017. pdf/b01f0af1-3285-fcefe19a-4af0a41c833b

Beane TP, Ennis DM (1987) Market segmentation: a review. European Journal of Marketing 21 (5): 20-42. https://doi.org/10.1108/EUM0000000004695

Belás J, Dvorský J, Kubálek J, Smrčka L (2018) Important factors of financial risk in the SME segment. Journal of International Studies 11 (1): 80-92. https://doi.org/10.14254/2071-8330.2018/11-1/6

Belás J, Ključnikov A, Vojtovič S, Sobeková-Májková M (2015) Approach of the SME entrepreneurs to financial risk management in relation to gender and level of education. Economics and Sociology. https://doi.org/10.14254/2071-789X.2015/8-4/2

Barrera GA (2017) Relación de Capacitación con Adopción de Internet y E-Commerce: Diferencias entre Microemprendedores de Chile. Información tecnológica 28 (6): 61-70. https:// doi.org/10.4067/S0718-07642017000600008

Benito-Hernández S, Platero-Jaime M, Rodríguez-Duarte A (2012) Factores determinantes de la innovación en las microempresas españolas: La importancia de los factores internos. Universia Business Review (33).

Bianchi C, Mathews S (2016) Internet marketing and export market growth in Chile. Journal of Business Research 69 (2): 426-434. https://doi.org/10.1016/j.jbusres.2015.06.048

Blanco Lora I, Segarra-Oña M (2014) Estudio exploratorio del uso del e-marketing como una estrategia para micro, pequeñas y medianas empresas de servicios. Revista PUENTE Científica 7 (2).

Bosma N, Levie J (2009) Global Entrepreneurship Monitor: 2009 Global Report. London: Global Entrepreneurship Monitor Consortium.

Cecere A, Acatitla E (2016) El comercio electrónico (e-commerce): una posible ventana de oportunidad para las firmas en los países en vías de desarrollo. Revista Internacional de Investigación y Docencia 1 (1): 12.

CEPAL (2016) Estado de la banda ancha en América Latina y el Caribe 2016 https://repositorio.cepal.org/bitstream/ handle/11362/40528/6/S1601049_es.pdf

Cerón Bracamontes M, Azpeitia Torres ER, Tapia Rivera JC, Rivera Espinoza M (2018) Las tecnologías de la información y comunicación en las micro, pequeñas y medianas empresas en el sur de jalisco. Revista Global de Negocios 6 (1): 1-13. 
Chatzoglou P, Chatzoudes D (2016) Factors affecting e-business adoption in SMEs: an empirical research. Journal of Enterprise Information Management 29 (3): 327-358. https://doi. org/10.1108/jeim-03-2014-0033

Coleman S (2000) Access to capital and terms of credit: A comparison of men-and women-owned small businesses. Journal of small business management 38 (3): 37.

Cueva ÁR (2012) Aprende a emprender: Universidad y emprendimiento. Revista de estudios de juventud (99): 69-87.

De Sena A (2014) Promoción de microemprendimentos y políticas sociales: ¿Universalidad, focalización o masividad?, Una discusión no acabada. Pensamento Plural (8): 37-63.

Denby EH (1989) Psychographics revisited: The birth of a technique. Marketing News, Jan 2: 21.

Devins D (2009) Enterprise in deprived areas: What role for start-ups? International Journal of Entrepreneurship and Small Business 8 (4): 486-498. https://doi.org/10.1504/IJESB.2009.025694

Dueñas PPM, Franco JJMT, Fernández JL (2018) La comunicación en las empresas de distribución alimentaria en España: un análisis de las herramientas online y offline. Revista de la SEECI 22 (45): 55-73.

https://doi.org/10.15198/seeci.2018.45.55-73

Duman L, Bedük A, Köylüoğlu AS, Ay K (2015) Entrepreneurship culture at SMEs: A case study in Konya. Procedia-social and behavioral sciences 207: 492-501.

https://doi.org/10.1016/j.sbspro.2015.10.119

Durán M, Ignacio M (2015) Factores críticos en la adopción de las tecnologías de la información en microempresas del rubro talleres mecánicos de la comuna de Chillán (tesis de pregrado). Facultad de Ciencias Empresariales Contador Público y Auditor, Universidad de Bío Bío, Chile.

Eniola AA (2018) Entrepreneur-SME Manager Traits and Sources of Financing. In African Entrepreneurship (pp. 223-259). Palgrave Macmillan, Cham. https://doi.org/10.1007/978-3319-73700-3_10

Esmaeilpour M, Hoseini SY, Jafarpour Y (2016) An empirical analysis of the adoption barriers of e-commerce in small and medium sized enterprises (SMEs) with implementation of technology acceptance model. The Journal of Internet Banking and Commerce 21 (2).

Espelt NG, Fernández JM, Casellas DV (2000) Patrimonio cultural y turismo: nuevos modelos de promoción vía Internet. Cuadernos de turismo (6): 73-88.

Fillis I, Johansson U, Wagner B (2003) A conceptualisation of the opportunities and barriers to e-business development in the smaller firm. Journal of Small Business and Enterprise Development 10 (3): 336-344. https://doi.org/10.1108/14626000310489808

Flores M, Ramírez Urquidy M, Aguilar Barceló JG (2016) Microempresas de base social y sus posibilidades de supervivencia. Contaduría y administración 61 (3): 551-567. https://doi.org/10.1016/j.cya.2015.04.001

Frank H, Lueger M, Korunka C (2007) The significance of personality in business start-up intentions, start-up realization and business success. Entrepreneurship \& Regional Development 19 (3): 227-251. https://doi.org/10.1080/08985620701218387

García-Cabrera AM, García-Soto MG, Durán-Herrera JJ (2017) Motivación por oportunidad del emprendedor e internacionalización de la actividad de la Pyme. Emprendimiento y Negocios Internacionales 2 (2): 6-16.

https://doi.org/10.20420/eni.2017.188

Gilmore A, Gallagher D, Henry S (2007) E-marketing and SMEs: operational lessons for the future. European Business Review 19 (3): 234-247. https://doi.org/10.1108/09555340710746482

Gómez EAF, Gómez EIF (2004) Conocimientos y aplicaciones tecnológicas para la dirección comercial. ESIC Editorial.

Grilo I, Thurik R (2004) Determinants of entrepreneurship in Europe. Group Entrepreneurship, Growth and Public Policy, MPI, Jena.

Grzegorz S, Robert S (2018) The use of marketing innovations among SMES. Journal of Fundamental and Applied Sciences 10 (3S): 257-267.

Gupta N, Mirchandani A (2018) Investigating entrepreneurial success factors of women-owned SMEs in UAE. Management Decision 56 (1): 219-232.

https://doi.org/10.1108/MD-04-2017-0411

Gutiérrez-Leefmans C, Nava-Rogel RM (2016) Mercadotecnia digital y las pequeñas y medianas empresas: revisión de la literatura. Enl@ce: Revista Venezolana de Información, Tecnología y Conocimiento 13 (1): 45-61.

Harindranath G, Dyerson R, Barnes D (2008, June) ICT in small firms: factors affecting the adoption and use of ICT in Southeast England SMEs. In ECIS (pp. 889-900).

Henry C, Hill F, Leitch C (2017) Entrepreneurship education and training: the issue of effectiveness: the issue of effectiveness. Routledge. https://doi.org/10.4324/9781315197227

Huang B, Shaban M, Song Q, Wu Y (2018) E-commerce development and entrepreneurship in the People's Republic of China (No. 827). ADBI Working Paper Series.

Huaroto CA (2012) Efecto de la adopción de Internet en la productividad: Evidencia desde una muestra de microempresas en el Perú. In Actas de la VI Conferencia ACORNREDECOM, Valparaíso (Chile) (pp. 17-18).

Ihlström Eriksson C, Kalling T, Åkesson M, Fredberg T (2008) Business Models for M-Service - exploring the e-newspaper case from a consumer view. Journal of Electronic Commerce in Organizations 6 (2). https://doi.org/10.4018/jeco.2008040103

Johnson M (2010) Barriers to innovation adoption: a study of e-markets. Industrial Management \& Data Systems 110 (2): 157-174. https://doi.org/10.1108/02635571011020287

Jones C, Motta J, Alderete MV (2016) Gestión estratégica de tecnologías de información y comunicación y adopción del comercio electrónico en Mipymes de Córdoba, Argentina. Estudios Gerenciales 32 (138): 4-13. https://doi.org/10.1016/j.estger.2015.12.003

Jones P, Beynon-Davies P, Muir E (2003) Ebusiness barriers to growth within the SME sector. Journal of Systems and Information Technology 7 (1/2): 1-25. https://doi.org/10.1108/13287260380000771

Kantis H, Ishida M, Komori M (2002) Empresarialidad en economías emergentes: Creación y desarrollo de nuevas empresas en América Latina y el Este de Asia. Inter-American Development Bank.

Kickul J, Wilson F, Marlino D, Barbosa SD (2008) Are misalignments of perceptions and self-efficacy causing gender gaps in 
entrepreneurial intentions among our nation's teens? Journal of Small Business and Enterprise Development 15 (2): 321 335. https://doi.org/10.1108/14626000810871709

Kirkwood J (2009) Motivational factors in a push-pull theory of entrepreneurship. Gender in Management: An International Journal 24 (5): 346-364. https://doi.org/10.1108/17542410910968805

Koh HC (1996) Testing hypotheses of entrepreneurial characteristics. Journal of Managerial Psychology 11 (3): 12-25. https:// doi.org/10.1108/02683949610113566

Kozubíková L, Homolka L, Kristalas D (2017) The effect of business environment and entrepreneurs' gender on perception of financial risk in the smes sector. Journal of Competitiveness. https://doi.org/10.7441/joc.2017.01.03

Kuratko DF, Hornsby JS, Naffziger DW (1997) An examination of owner's goals in sustaining entrepreneurship. Journal of small business management 35 (1): 24 .

Laudon KC, Laudon JP (2008) Sistemas de Información Gerencial-Administración de la empresa digital (10ma Ed). México, DF.

Laukkanen M (2000) Exploring alternative approaches in high-level entrepreneurship education: creating micromechanisms for endogenous regional growth. Entrepreneurship \& Regional Development 12 (1): 25-47. https://doi. org/10.1080/089856200283072

Lawrence JE, Tar UA (2010) Barriers to e-commerce in developing countries. Information, Society and Justice Journal 3 (1): 23-35.

Liñán F, Fernández J, Martínez-Román JA (2016) Entrepreneurship education in Andalusia. An embedded approach. Journal for Educators, Teachers and Trainers 6 (2).

Machmud S, Sidharta I (2016) Entrepreneurial motivation and business performance of SMEs in the SUCI clothing center, Bandung, Indonesia. DLSU Business \& Economics Review 25 (2).

Matos CS, Amaral M, Baptista R (2018) Senior Entrepreneurship: A Selective Review and a Research Agenda. Foundations and Trends ${ }^{\circledast}$ in Entrepreneurship 14 (5): 427-554. https://doi. org/10.1561/0300000084

McClelland DC (1961) The achieving society. Princeton, NJ: D. Van Norstrand Company. Inc., 1961. https://doi.org/10.1037/14359-000

Mele N (2013) The end of big business: Being big used to be a competitive advantage, but the proliferation of digital technology means small businesses will be the champions of tomorrow. Billboard 125 (21): 17.

Messeghem K (2003) Strategic entrepreneurship and managerial activities in SMEs. International Small Business Journal 21 (2): 197-212. https://doi.org/10.1177/0266242603021002004

Ministry of Economy, Development and Tourism of Chile (n.d.) Quinta Encuesta de Microemprendimiento de Chile (EME5) http://www.economia.gob.cl/2018/02/13/quinta-encuesta-demicroemprendimiento-eme5.htm, revisado en abril de 2018

Ministry of Economy, Development and Tourism of Chile (2016) Informe de resultados: El microemprendedor en Chile - Cuarta encuesta de microemprendimiento 2015 http://www. economia.gob.cl/wp-content/uploads/2016/02/Informe-deresultados-elmicroemprendedor-en-Chile.pdf
Moreno JDJ (2013) Análisis de los factores que influyen en la intención emprendedora de los estudiantes universitarios. Caracciolos 1 (1).

Nasco SA, Toledo EG, Mykytyn Jr PP (2008) Predicting electronic commerce adoption in Chilean SMEs. Journal of $\mathrm{Bu}-$ siness Research 61 (6): 697-705. https://doi.org/10.1016/j. jbusres.2007.06.047

Nikunen T, Saarela M, Oikarinen EL, Muhos M, Isohella L (2017). Micro-Enterprise's digital marketing tools for building customer relationships. Management (18544223) 12(2). https://doi. org/10.26493/1854-4231.12.171-188

O’Regan N, Sims M, Ghobadian A (2005) High performance: ownership and decision-making in SMEs. Management Decision 43 (3):382-396. https://doi.org/10.1108/00251740510589760

Orser BJ, Riding A (2018) The influence of gender on the adoption of technology among SMEs. International Journal of Entrepreneurship and Small Business 33 (4): 514-531. https://doi. org/10.1504/IJESB.2018.090341

Pascucci F, Cardinali S, Gigliarano C, Gregori GL (2017) Internet adoption and usage: evidence from Italian micro enterprises. International Journal of Entrepreneurship and Small Business 30 (2): 259-280. https://doi.org/10.1504/IJESB.2017.081440

Pessoa de Matos M, Arroio A (2011) Políticas de apoyo a micro y pequeñas empresas en Brasil: avances recientes y perspectivas. En: Apoyando a las pymes: políticas de fomento en América Latina y el Caribe. Santiago: CEPAL, 2011 (pp. 77-164). LC/R. 2180.

Platero-Jaime M, Benito-Hernández S, Rodríguez-Duarte A (2017) The moderator effect of training in the adoption of ICT in microenterprises. Cuadernos de Gestión 17 (2). https:// doi.org/10.5295/cdg.150539mp

Porter ME (1980) Competitive strategy. Techniques for analayzing industries and competitors, The Fress Press, Nueva York.

Rahayu R, Day J (2015) Determinant factors of e-commerce adoption by SMEs in developing country: evidence from Indonesia. Procedia-Social and Behavioral Sciences 195: 142150. https://doi.org/10.1016/j.sbspro.2015.06.423

Reynolds PD, Bygrave W, Autio E, y Hay M (2002) Global Entrepreneur-ship Monitor. 2002 Summary Report. Ewin Marion Kauffman Foundation, Kansas City.

Rodríguez Ramírez A (2008) El emprendimento en Colombia. Entramado 4 (2).

Rose G, Khoo H, Straub DW (1999) Current technological impediments to business-to-consumer electronic commerce. Communications of the AIS 1 (5es): 1. https://doi.org/10.17705/1CAIS.00116

Saavedra García ML, Tapia Sánchez B (2013) El uso de las tecnologías de información y comunicación TIC en las micro, pequeñas y medianas empresas (MIPyME) industriales mexicanas. Enl@ce: Revista Venezolana de Información, tecnología y conocimiento 10 (1).

Sánchez P (2012) Comunicación y atención al cliente. Editex.

Sandberg KW, Håkansson F (2014). Barriers to adapt eCommerce by rural microenterprises in Sweden: a case study. International Journal of Knowledge and Research in Management and E-Commerce 4 (1): 1-7.

Shah A, Patel R (2016) E-Commerce and rural handicraft artisans. Tourism, leisure and Global change 1 (1): 10, 24. 
Sin Tan K, Choy Chong S, Lin B, Cyril Eze U (2010) Internetbased ICT adoption among SMEs: Demographic versus benefits, barriers, and adoption intention. Journal of enterprise information management 23 (1): 27-55. https://doi. org/10.1108/17410391011008897

Singh M (2002) E-services and their role in B2C e-commerce. Managing Service Quality: An International Journal 12 (6): 434-446. https://doi.org/10.1108/09604520210451911

Sirec K, Mocnik D (2010) How entrepreneurs' personal characteristics affect SMES' growth. Nase Gospodarstvo: NG 56 (1/2): 3 .

Stephan U, Hart M, Mickiewicz T, Drews CC (2015) Understanding motivations for entrepreneurship. BIS Research paper, 212.

Stephan U, Hart M, Drews CC (2015) Understanding motivations for entrepreneurship: A review of recent research evidence. Enterprise Research Centre and Aston Business School, Birmingham, UK.

Tarute A, Gatautis R (2014) ICT impact on SMEs performance. Procedia-Social and Behavioral Sciences 110: 1218-1225. https://doi.org/10.1016/j.sbspro.2013.12.968

Teo TS (2001) Demographic and motivation variables associated with Internet usage activities. Internet Research 11 (2): 125137. https://doi.org/10.1108/10662240110695089
Weber P, Schaper M (2004) Understanding the grey entrepreneur. Journal of enterprising culture 12 (02): 147-164. https://doi. org/10.1142/S0218495804000087

Werner A, Schröder C, Chlosta S (2018) Driving factors of innovation in family and non-family SMEs. Small Business Economics 50 (1): 201-218. https://doi.org/10.1007/s11187017-9884-4

Wilson KE (2008) Entrepreneurship education in Europe. Entrepreneurship and Higher Education.

Yalcin S, Kapu H (2008) Entrepreneurial dimensions in transitional economies: A review of relevant literature and the case of Kyrgyzstan. Journal of Developmental Entrepreneurship 13 (02): 185-204. https://doi.org/10.1142/S1084946708000922

Yu H, Cui L (2019) China’s E-Commerce: empowering rural women? The China Quarterly, 1-20. https://doi.org/10.1017/ S0305741018001819

Zali MR, Faghih N, Ghotbi S, Rajaie S (2013) The effect of necessity and opportunity driven entrepreneurship on business growth. International Research Journal of Applied and Basic Sciences 7 (2): 100-108.

Zwillenberg P, Field D, Dean D (2014) The connected world: Greasing the wheels of the Internet economy. Boston Consulting Group. 